\title{
Mangrove Rehabilitation in Bengkulu City
}

\author{
P. P. Renta*, Y. H. Saputra, D. Purnama, and Zamdial \\ Marine Science Study Program, Agriculture Faculty, University of Bengkulu, Bengkulu, Indonesia \\ *Corresponding author Email: pprenta@unib.ac.id
}

\begin{abstract}
Mangrove rehabilitation is an activity to replant mangrove ecosystems that have been damaged. This study aimed to measure the physical condition of rehabilitated mangroves, analyze the role of the government, and measure community perceptions, aspirations and actions in mangrove rehabilitation activities. This research was conducted in August - October 2019 at Lentera Merah and Badrika Mangrove Tourism Park, Bengkulu City. The data collection of mangrove vegetation structure used purposive sampling method, while the respondent's data collection used the insindental method. The results showed that the mangrove vegetation structure data in Lentera Merah could not be calculated, while in the Badrika Mangrove Tourism Park there were two types of mangroves found (Rhizophora apiculata and Sonneratia alba) which were categorized as saplings and seedlings. The government agency that has carried out mangrove rehabilitation was the Environment and Forestry Service (DLHK) and Watershed and Protection Forest Management Centers (BPDASHL) Ketahun. The government had a funding role in the form of providing seedlings, but the government had not yet carried out counseling activities. The government had not yet monitored and evaluated the rehabilitation activities at Lentera Merah, while in the Badrika Mangrove Tourism Park these activities had been carried out. The level of community perceptions, aspirations and actions in mangrove ecosystem rehabilitation activities in the two locations was categorized as moderate.
\end{abstract}

Keywords: mangrove, rehabilitation, government, vegetation structure, community

\section{INTRODUCTION}

Mangrove ecosystems can be interpreted as ecosystems that grow in coastal areas which are affected by the tides of sea water so that the floors are always flooded so that mangroves have strong roots and are able to protect the shoreline from abrasion [1]. This ecosystem supports various ecosystems along the coastline in tropical areas such as coastal areas that are scattered in Indonesia [2].

The area of the mangrove ecosystem in Indonesia is currently estimated to have left 1.2 million hectares [3]. The mangrove ecosystem in Bengkulu City is scattered, not on a large expanse, according to 2016 PRL statistical data, the area of the mangrove ecosystem in Bengkulu City is 117.5 hectares, with good condition 53.5 hectares, moderate condition 34 hectares, and damaged 30 hectares.

Damage to the mangrove ecosystem in Bengkulu City occurred due to the conversion of mangrove ecosystem land into residential areas, aquaculture, oil palm plantations, as building material and firewood as well as the accumulation of sand in the mangrove ecosystem area. Overuse has resulted in a decrease in the area of the mangrove ecosystem, such as in Panjang Beach area and Pulau Baai which were included in the Kampung Melayu sub-district [4]. Damage to the mangrove forest ecosystem has a negative impact on the availability of fish resources and the risk of flooding [5].
Mangrove ecosystems have the ability to improve their own habitat by developing growth and development, as well as regeneration. However, the rate of mangrove damage is faster and cannot be matched by the rate of natural recovery, especially if there is a change in the physical condition of the habitat to an abnormal direction and changes in the hydrological system [6]. Therefore, human assistance is needed to accelerate the rate of recovery of mangrove damage by rehabilitating potential mangrove damaged areas. Mangrove ecosystem rehabilitation is the replanting of mangrove ecosystems that have been damaged. In order for rehabilitation to run effectively and efficiently, it is necessary to precede a survey to determine potential areas for rehabilitation based on an assessment of its physical and vegetation conditions [7].

Many mangrove rehabilitation programs have been carried out in Bengkulu City, but the mangrove rehabilitation activities have not been fully successful, even if there is a tendency for disturbances due to differences in interests with the community. This study was conducted to determine the factors (both supporting and inhibiting factors) that influence the success rate of the rehabilitation program in the area so that it can be taken into consideration in further better rehabilitation activities. 


\section{MATERIALS AND METHODS}

\subsection{Method of Determination of Sampling Location}

The sampling location of this study was determined based on the presence of rehabilitated mangrove vegetation in Bengkulu City. Data on the location of mangrove rehabilitation activities can be obtained from interviews with government agencies related to mangrove rehabilitation activities.

\subsection{Method of Collecting Data}

This research was divided into several parts including the collection of data on vegetation structure, vegetation composition, water quality, rainfall, soil texture types, local government regulations, the role of institutions, and community perceptions, aspirations and actions.

\subsubsection{Structure and Composition of Mangrove Vegetation}

Data on the structure and composition of mangrove vegetation were measured in situ using a transect method consisting of 3 different plot sizes [8]. Each research station had 3 transect points and each transect point contains 3 plots measuring $10 \times 10 \mathrm{~m}, 5 \times 5$ $\mathrm{m}$, and $1 \mathrm{x} 1 \mathrm{~m}$. Each plot had a different function based on the diameter of the mangrove stems. Vegetation sampling includes trees, saplings, and seedlings.

\subsubsection{Water Quality}

Water quality data at the research station were measured in situ using 3 repetitions at each sampling point. Water quality parameters measured include temperature, salinity and $\mathrm{pH}$.

\subsubsection{Data on Government Institutions Related to Mangrove Rehabilitation and Management}

Data were collected from government agencies that play a role in the mangrove rehabilitation program at the research location. The data were obtained through interviews with several resource persons in each agency including the Environment and Forestry Service (DLHK) and Watershed and Protection Forest Management Centers (BPDASHL) Ketahun.

\subsubsection{Data on Community Perceptions, Aspirations and Actions in Mangrove Rehabilitation}

Data on community perceptions, aspirations and actions in mangrove rehabilitation were obtained through filling out a questionnaire given to several respondents in each research location. Respondents selected were residents who live around the mangrove rehabilitation location and community leaders who know about mangrove rehabilitation activities in the research location. Respondent categories were people who have activities around the research location, such as fishermen, farmers, housewives, traders and employees. The number of respondents was involved based on survey research standards is at least 30 people [9].

\subsection{Data Analysis}

Data obtained from in-situ measurements in the field and secondary data were analyzed descriptively in the form of graphs or tables so as to produce a detailed description of the current condition of the mangroves and the rehabilitation activities that have been carried out.

\subsubsection{Data Analysis on Structure and Composition of Mangrove Vegetation}

The data obtained from the in-situ measurement was carried out by analyzing the mangrove vegetation which included the value of Density (K), Basal Area (BA), Relative Density (KR), Relative Dominance (DR), Important Value (NP), Diversity Index ( $\left.\mathrm{H}^{\prime}\right)$ and Uniformity Index (J ') Dominance Index (D).

\subsubsection{Analysis of Water Parameter Data}

Parameter data obtained from in-situ measurements at the research location were analyzed descriptively.

\subsubsection{Analysis of Institutional Data, Role of Institutions and Local Government Regulations Related to Mangrove Rehabilitation and Management}

Data obtained from interviews regarding the existence of institutions, the role of institutions and local government regulations were analyzed descriptively to describe the roles of local government institutions and regulations that exist in each research location that participate in mangrove management and rehabilitation.

\subsubsection{Data Analysis on Percentage of Community Perceptions, Aspirations and Actions in Mangrove Rehabilitation}

Data obtained from a questionnaire regarding the perceptions, aspirations and actions of the community in the Bengkulu City rehabilitation program were analyzed descriptively with percentage data. Furthermore, the value of each respondent was added and made a ranking with a rating scale according to [10], as follows:

Research Score $=\sum$ Respondents x Value

Ideal Score $=\sum$ Respondents $\times 3 \times$ Questions

Percentage $(\%)=($ research score $) /($ ideal score $) \times 100$ 
The level of community perceptions, aspirations and actions in mangrove ecosystem rehabilitation activities is grouped based on the load score into three categories.
The load score categories are presented in Table 1 . below:

Table 1. Constraints on Payload Scores for Percentage Analysis

\begin{tabular}{|c|c|}
\hline Payload Score & Category \\
\hline $0-33,33 \%$ & Low \\
\hline $33,34-66,67 \%$ & Moderate \\
\hline $66,68-100 \%$ & High \\
\hline
\end{tabular}

\section{RESULTS AND DISCUSSION}

\subsection{Location Overview}

The research was conducted in two locations, the first location was included in Lentera Merah, Kampung Melayu District, Bengkulu City and the second location was the Badrika Mangrove Tourism Park, Gading Cempaka District, Bengkulu City. The location determination was based on the results of interviews with government agencies related to mangrove rehabilitation activities which indicated that there were two locations for mangrove rehabilitation activities in Bengkulu City.

\subsection{Physical Condition of Mangroves Result of Rehabilitation Activities at Research Sites}

\subsubsection{Physical Condition of Mangroves in Lentera Merah}

Mangroves with the categories of trees, saplings and seedlings were not found in Lentera Merah so the value of the structure of the mangrove vegetation composition could not be calculated. The condition of the mangrove rehabilitation results that have been carried out cannot be counted because only a few seedlings are alive and the seedlings are also scattered. According to interviews with government agencies that carry out mangrove rehabilitation, the mangroves that have been planted were disturbed by wild animals such as predation of mangrove seeds by buffalo. Therefore, after planting for some time, the institution installed a net to prevent disturbance by wild animals. Propagule predation is the main factor causing propagules to not survive [12]. In addition, propagule predation also affects the growth and distribution patterns of mangroves [13].

Limiting factors for the mangrove environment include physical and chemical factors and human activities, both directly and indirectly [14]. In addition, public awareness of the benefits of mangroves is still lacking, so they tend not to protect and preserve the mangrove environment as well still releasing wild buffalo.

The success of mangrove rehabilitation activities can also be influenced by those who carry out these activities. At this location, monitoring and evaluation activities have not been carried out. This can be seen from the conditions in the field where the mangrove seedlings are not replanting or replacing dead mangrove seeds. Therefore, it is necessary for the roles of all parties, both government agencies and the surrounding community to make the mangrove rehabilitation activities a success.

\subsubsection{Physical Condition of Mangroves in Badrika Mangrove Tourism Park}

\subsubsection{Tree Category}

Tree categories are not found in the Badrika Mangrove Tourism Park, so the value of the structure of the mangrove vegetation composition cannot be calculated. This is because the rehabilitation activities at that location began in 2018 so that tree characteristics were not found.

\subsubsection{Sapling Category}

The density (Den) of mangrove vegetation in the Badrika Mangrove Tourism Park in the sapling category was 2300 ind / ha, where there is only one species, namely Sonneratia alba. The Basal Area (Ab) value for Sonneratia alba species was 162.58. The relative density (RD) and relative dominance (DR) were $100 \%$ owned by Sonneratia alba species. Meanwhile, the Important Value (IV) owned by Sonneratia alba was $200 \%$. The Diversity Index ( $\left.\mathrm{H}^{\prime}\right)$ of mangrove vegetation in the Badrika Mangrove Tourism Park in the sapling category was 0 . While the Uniformity Index $\left(\mathrm{J}^{\prime}\right)$ was 0 because only one species was found, namely Sonneratia Alba. The value of the mangrove vegetation composition structure of the sapling category in the Badrika Mangrove Tourism Park is presented in Table 2. 
Table 2. Structure of Mangrove Vegetation Composition Sapling Category in Badrika Mangrove Tourism Park, Bengkulu City.

\begin{tabular}{|c|c|c|c|c|c|c|c|c|c|c|c|}
\hline \multirow[b]{2}{*}{ Location } & \multirow[b]{2}{*}{ No } & \multirow[b]{2}{*}{ Species } & \multicolumn{9}{|c|}{ Sapling } \\
\hline & & & ni & $\begin{array}{c}\text { Den } \\
\text { (ind/ha) }\end{array}$ & $\mathrm{Ab}\left(\mathrm{cm}^{2}\right)$ & $\begin{array}{l}\text { RD } \\
(\%)\end{array}$ & $\begin{array}{l}\text { DR } \\
(\%)\end{array}$ & $\begin{array}{l}\text { IV } \\
(\%)\end{array}$ & $\mathbf{H}^{\prime}$ & $\mathbf{J}^{\prime}$ & D \\
\hline $\begin{array}{c}\text { Badrika Mangrove } \\
\text { Tourism Park }\end{array}$ & 1 & $\begin{array}{l}\text { Sonneratia } \\
\quad \text { Alba }\end{array}$ & 23 & 2300 & 162,58 & 100 & 100 & 200 & 0 & & \\
\hline & & Total & 23 & 2300 & 162,58 & 100 & 100 & 200 & 0 & 0 & 1 \\
\hline Information : & $\begin{array}{l}\text { ni } \\
\text { Den } \\
\text { Ab } \\
\text { RD } \\
\text { DR } \\
\text { IV } \\
\text { H' } \\
\text { J' } \\
\text { D }\end{array}$ & $\begin{array}{l}\text { number of indiv } \\
\text { : Density } \\
\text { Basal Area } \\
\text { Relative Density } \\
\text { Relative Domin } \\
\text { Important Value } \\
\text { Diversity Index } \\
\text { Uniformity Inde } \\
\text { Dominance Inde }\end{array}$ & ace & e -i species & & & & & & & \\
\hline
\end{tabular}

\subsubsection{Seedling Category}

The density (Den) of mangrove vegetation in the Badrika Mangrove Tourism Park in the seedling category was 400 ind / ha, of which there are 2 species, namely Sonneratia Alba and Rhizophora apiculata. The value of Relative Density (RD) and Relative
Dominance (DR) of both species was $100 \%$. Important Value (IV) was $200 \%$. The Diversity Index (H ') of mangrove vegetation in the Badrika Mangrove Tourism Park in the seedling category was 0.163 . Its Uniformity Index ( $\mathrm{J} ')$ was 0.236 . The structural value of mangrove vegetation composition for seedling categories in Badrika Mangrove Tourism Park was presented in detail in Table 3.

Table 3. Structure of Mangrove Vegetation Composition in the category of seeding in Badrika Mangrove Tourism Park, Bengkulu City.

\begin{tabular}{|c|c|c|c|c|c|c|c|c|c|c|}
\hline \multirow[b]{2}{*}{ Location } & \multirow[b]{2}{*}{ No } & \multirow[b]{2}{*}{ Species } & \multicolumn{8}{|c|}{ Seedling } \\
\hline & & & ni & Den & $\begin{array}{l}\text { RD } \\
(\%)\end{array}$ & $\begin{array}{l}\text { DR } \\
(\%)\end{array}$ & $\begin{array}{l}\text { IV } \\
(\%)\end{array}$ & $\mathbf{H}^{\prime}$ & $\mathbf{J}^{\prime}$ & D \\
\hline \multirow{3}{*}{$\begin{array}{c}\text { Badrika } \\
\text { Mangrove } \\
\text { Tourism Park }\end{array}$} & 1 & $\begin{array}{c}\text { Sonneratia } \\
\text { alba }\end{array}$ & 1 & 50 & 12,5 & 83,3 & 95,83 & & & 0,015 \\
\hline & 2 & $\begin{array}{c}\text { Rhizophora } \\
\text { apiculata }\end{array}$ & 7 & 350 & 87,5 & 16,7 & 104,16 & & & 0,765 \\
\hline & & Total & 8 & 400 & 100 & 100 & 200 & 0,163 & 0,236 & 0,781 \\
\hline \multicolumn{11}{|c|}{$\begin{array}{l}\text { ni : number of individuals of the }- \text { i species } \\
\text { Den : Density } \\
\text { Ab : Basal Area } \\
\text { RD : Relative Density } \\
\text { DR : Relative Dominance } \\
\text { IV : Important Value } \\
\text { H': Diversity Index } \\
\text { J' : Uniformity Index } \\
\text { D : Dominance Index }\end{array}$} \\
\hline
\end{tabular}

The results of the vegetation analysis showed that the mangrove vegetation density value for the sapling category in Badrika Mangrove Tourism Park was $2300 \mathrm{ind} / \mathrm{ha}$. Meanwhile, the density value for the seedling category in the Badrika Mangrove Tourism Park is 400 ind / ha. This mangrove density is an indicator of the condition of a mangrove forest in a place. Density is the number of individuals of a plant species in a certain area [15]. The density of a type is a value that indicates the number or number of types per unit area. The greater the density of a species, the more individuals of that species per unit area. Provisions regarding the density and thickness of mangrove forests are regulated in the Decree of the State Minister for the Environment number 201 of 2004 concerning Standard Criteria and Guidelines for Determining Mangrove Damage which are divided into three categories, namely rarely <1000 trees / hectare, moderate $\geq 1000$ - $<1500$ trees / hectare, and very dense $\geq 1500$ trees / hectare [16]. Based on the density criteria, the condition of the mangrove ecosystem as a result of rehabilitation in the Badrika Mangrove Tourism Park has a high density of the sapling category and must be preserved because the mangrove ecosystem has a very important ecological function for Bengkulu City, especially the Bengkulu Mangrove Tourism Park. The ecological functions of the mangrove ecosystem include preventing sea water intrusion, preventing abrasion, and habitat for wildlife.

Mangrove Diversity Index ( $\left.\mathrm{H}^{\prime}\right)$ for sapling category $(0)$ and seedling category $(0.16363)$ in Badrika Mangrove Tourism Park. There was dominance for the sapling category in Wista Mangrove Badrika Park because only one species was found so 
that the diversity index value was zero $\left(H^{\prime}=0\right)$. If the value of the dominance index is between 0.5-1 $(0.5<\mathrm{D}$ $<1)$ then there are species that dominate in the area [17]. Domination is a value that shows the dominance of a type over the community [18]. Dominance can be expressed by using the canopy cover area or the basal area.

The results of data analysis showed that the species that had the highest importance for the sapling category in the Badrika Mangrove Tourism Park was Sonneratia alba, while the important value for the seedling category in the Badrika Mangrove Tourism Park was Rhizophora apiculata. Importance Value (IV) is an index of importance used to express the level of dominance of species in a plant community [18]. This index states the importance of a plant species and also describes the level of control of the species in the community. The use of value index is important in determining the dominance of species in a community because density, dominance and frequency cannot be used individually to indicate the relative position of species in a plant community. The Importance Value Index is the sum of all the values of Relative Frequency (FR), Relative Density (RD) and Relative Dominance (DR) of each species.

An area that is only dominated by certain types, then the area is said to have low species diversity [18]. Areas that are only dominated by certain species have an influence on the level of species diversity. Whether or not mangrove growth in a community can be seen from the analysis of its vegetation condition, which shows the size of the role of a species in the existing community. This situation can be seen in the Importance Value Index of a mangrove species [19].

The results of the vegetation condition analysis can be used as a consideration in carrying out mangrove rehabilitation efforts. Analysis of plant vegetation is a way of studying the composition (species composition) and form (structure) of vegetation [18] [20]. Vegetation analysis requires quantitative data to determine the important value index and diversity index of the constituents of ecosystem communities so that quantitative information can be obtained about the structure, species abundance, vegetation distribution in an ecosystem, and the relationship between plant existence and environmental factors [21]. Apart from being supported by vegetation condition data, mangrove rehabilitation efforts must also pay attention to the carrying capacity of the environment, because the carrying capacity of the environment greatly influences the success of mangrove rehabilitation.

\subsection{Water Parameters}

Water parameters in Lentera Merah and Badrika Mangrove Tourism Park are presented in Table 4.

Table 4. Parameters of Lentera Merah Waters and Badrika Mangrove Tourism Park.

\begin{tabular}{|c|c|c|c|c|}
\hline \multirow{2}{*}{ Location } & \multicolumn{3}{|c|}{ Water Parameters } \\
\cline { 2 - 5 } & $\begin{array}{c}\text { Temperture } \\
\left({ }^{\circ} \mathbf{C}\right)\end{array}$ & Salinity (ppt) & $\mathbf{p H}$ & \multirow{2}{*}{ Substrat } \\
\hline \multirow{3}{*}{ Lentera Merah } & 33 & 36 & 7,2 & \multirow{2}{*}{ Sand } \\
\cline { 2 - 5 } & 34 & 37 & 7,1 & \\
\cline { 2 - 5 } & 34 & 36 & 7,1 & \multirow{2}{*}{ Sand } \\
\hline \multirow{3}{*}{ Badrika Mangrove Tourism P } & 32 & 32 & 7,5 & \\
\cline { 2 - 5 } & 31 & 34 & 7,5 & \\
\cline { 2 - 5 } & 31 & 34 & 7,5 & \multirow{2}{*}{} \\
\hline
\end{tabular}

\subsubsection{Temperature}

Temperature plays an important role in physiological processes (photosynthesis and respiration). The water temperature observed in Lentera Merah ranged from 33-34 ${ }^{\circ} \mathrm{C}$, while in the Badrika Mangrove Park, it was around $31-32^{\circ} \mathrm{C}$. Water temperature at the location is in the Quality Standard which states that the ideal sea water temperature for mangroves is 28-32 ${ }^{\circ} \mathrm{C}$ [22]. Mangroves can thrive in tropical areas in a temperature range of more than $20^{\circ} \mathrm{C}$ [23] [24].

\subsubsection{Salinity}

The salinity range observed at the time of the study for the Lentera Merah location was 36-37 ppt while in the Badrika Mangrove Tourism Park location was 32-34 ppt.
$\mathrm{pH}$ value at the research location can be categorized as ideal according to the quality standard [22]. This degree of acidity has an important role in biological and chemical processes in waters, alkaline waters (7-9) are productive waters and play a role in encouraging the process of changing organic matter in water into minerals that can be assimilated by phytoplankton [25].

\subsubsection{Substrate}

Substrate characteristics are a limiting factor for mangrove life [26]. The type of substrate greatly affects the type arrangement and density of the mangrove vegetation that lives on it. The more suitable the substrate is for certain types of mangrove vegetation, it can be seen from how dense the vegetation is in its living area. The results of the research in the two locations where the soil texture in Lentera Merah was obtained was 
sandy, as well as in the Badrika Mangrove Tourism Park which was sandy. The soil texture in the research location does not match the type of Rhizophora apiculata supported by Noor's statement which states that for Rhizophora apiculata this species generally grows on muddy, smooth, deep and stagnant soil during normal tide [27]. Rhizophora apiculata does not like hard substrates (with a high sand composition). Meanwhile, for Sonneratia alba, this type predominantly grows in the sandy soil texture [28].

\subsubsection{Rainfall}

Rainfall in both locations was more than 1000 $\mathrm{mm}$ / year, in Lentera Merah was 1,671 $\mathrm{mm}$ / year, and Badrika Mangrove Tourism Park was $1,825 \mathrm{~mm}$ / year [29]. The amount, duration and distribution of rain affect the development of mangrove plants. Rainfall that occurs affects air conditions, water temperature, water and soil salinity. The optimum rainfall at a location that can affect mangrove growth is in the range of $1500-3000 \mathrm{~mm} /$ year [30].

\subsection{The Role of Government Agencies in the Rehabilitation and Management of Mangroves}

\subsubsection{Role of Government Agencies in Rehabilitation Funding}

The results of the interviews with the related agencies showed that there were two governments carrying out mangrove rehabilitation activities in the research location, namely the Environment and Forestry Service (DLHK) and Watershed and Protection Forest Management Centers (BPDASHL) Ketahun. At the first location in Lentera Merah, the government agency carrying out mangrove rehabilitation activities is the Environment and Forestry Service (DLHK). Funding for mangrove rehabilitation activities in Lentera Merah is only in the form of providing seeds. Meanwhile, the second location is in the Badrika Mangrove Tourism Park, the government agency that carries out mangrove rehabilitation activities, namely Watershed and Protection Forest Management Centers (BPDASHL) Ketahun, the government also only provides ready-toplant seeds, the community itself is not directly involved in procuring mangrove seedlings. Funding in the form of money at the Badrika Mangrove Tourism Park in the form of wages to people who participate in the implementation of mangrove planting activities.

Funding is crutial aspect in an activity including mangrove ecosystem management, without sustainable funding support, the protection and utilization of mangrove ecosystems will not take place continuously. Funding for mangrove rehabilitation activities in the research locations comes from the government. Funding is very important for environmental management in Indonesia, including the rehabilitation of mangrove ecosystems in Bengkulu City. Mangrove rehabilitation activities will not run optimally without good funding.

\subsubsection{The Role of Government Agencies in Extension and Outreach}

There has never been any counseling and outreach done in the two research locations, either by Environment and Forestry Service (DLHK) and Watershed and Protection Forest Management Centers (BPDASHL) Ketahun. However, according to an interview with the Environment and Forestry Service (DLHK), the form of socialization of this service is by planting mangroves directly on site. Counseling and socialization activities aim to provide direction and explanation to the community regarding the function of rehabilitation and rehabilitation techniques or mangrove planting techniques [31]. Therefore it is necessary to do counseling and socialization before mangrove ecosystem rehabilitation activities to support the success of mangrove ecosystem rehabilitation.

In managing mangroves through protection, preservation and utilization for community welfare, the active role of all parties and groups, especially the community around the mangrove area, is needed. The local community will later become the main actors in the implementation of rehabilitation, protection and management of mangrove ecosystems. Mangrove education and outreach is beneficial in building public awareness to conserve the environment and protect mangroves.

\subsubsection{The Role of Government Agencies in Monitoring and Evaluation Activities}

In general, the term evaluation can be equated with interpretation, scoring, and assessment, words that express the purpose of analyzing a policy outcome in terms of the units of value. Evaluation with regard to information products regarding the value or benefits of a policy outcome. When the results of a policy in fact have value, this is because these results contribute to goals and objectives [32]. The main objective of implementing evaluation is to obtain information and draw lessons from experience regarding the implementation and management of a program or project (outputs, benefits, and impacts) either from programs that have not been completed or have served as a source for decision making for the next program [33].

The monitoring and evaluation of mangrove ecosystem rehabilitation activities by the Environment and Forestry Service (DLHK) at Lentera Merah, Bengkulu City has not been carried out. Meanwhile, monitoring and evaluation by the Watershed and Protection Forest Management Centers (BPDASHL) Ketahun in the Badrika Mangrove Tourism Park have been carried out, monitoring and evaluation activities are usually carried out several months after planting and these activities are not continuously carried out, so data on the graduation of plant life as a result of 
rehabilitation is still difficult to obtain. In addition, related parties have not yet planted the dead mangroves in the rehabilitation site. Monitoring and evaluation activities were carried out with the aim of knowing the boundaries, area, vegetation formation, density, level of utilization, level of damage, level of survival so that the success rate of the rehabilitation program could be determined. This activity should be carried out regularly and in the long term. The failure of rehabilitation was due to fragmented activities, where rehabilitation activities were considered complete after the seeds were planted [34].

\subsection{Perceptions, Aspirations and Community Actions in Mangrove Rehabilitation and Management}

\subsubsection{Perceptions of Mangrove Rehabilitation}

The results regarding respondents' perceptions about mangrove rehabilitation in the research location are presented in Table 5 .

Table 5. Recapitulation of Percentage of Calculation Results regarding Community Perceptions of Mangrove Rehabilitation Activities (a) Lentera Merah (b) Badrika Mangrove Tourism Park.

\begin{tabular}{|c|c|c|c|c|c|}
\hline \multirow{2}{*}{ No } & \multirow{2}{*}{ Questions } & \multicolumn{2}{|c|}{ Perceived Value $(\%)$} & \multicolumn{2}{|c|}{ Category } \\
\hline & & $\mathbf{a}$ & $\mathbf{b}$ & $\mathbf{a}$ & $\mathbf{b}$ \\
\hline 1 & Public perception about mangroves & 81 & 82 & $\mathrm{H}$ & $\mathrm{H}$ \\
\hline 2 & Functions and benefits of mangove ecosystem & 79 & 83 & $\mathrm{H}$ & $\mathrm{H}$ \\
\hline 3 & $\begin{array}{l}\text { Public perception of the existence of a mangrove } \\
\text { ecosystem around them }\end{array}$ & 90 & 97 & $\mathrm{H}$ & $\mathrm{H}$ \\
\hline 4 & Community perceptions about mangrove species & 43 & 51 & $\mathrm{M}$ & $\mathrm{M}$ \\
\hline 5 & $\begin{array}{l}\text { Public perception about the condition of the mangrove } \\
\text { ecosystem around them }\end{array}$ & 67 & 61 & $\mathrm{H}$ & $\mathrm{M}$ \\
\hline 6 & $\begin{array}{l}\text { Public perceptions about why the mangrove habitat was } \\
\text { destroyed in this area }\end{array}$ & 51 & 62 & $\mathrm{M}$ & $\mathrm{M}$ \\
\hline 7 & $\begin{array}{l}\text { Public perceptions about the functions and benefits of } \\
\text { ecosystem rehabilitation }\end{array}$ & 60 & 73 & M & $\mathrm{H}$ \\
\hline 8 & $\begin{array}{l}\text { Public perception about the mangrove rehabilitation } \\
\text { program }\end{array}$ & 38 & 37 & $\mathrm{M}$ & $\mathrm{M}$ \\
\hline 9 & $\begin{array}{l}\text { Public perception of government / non-government } \\
\text { institutions that assist in mangrove rehabilitation }\end{array}$ & 44 & 51 & $\mathrm{M}$ & $\mathrm{M}$ \\
\hline 10 & $\begin{array}{l}\text { Public perception about the supporting facilities and } \\
\text { infrastructure in the mangrove rehabilitation program }\end{array}$ & 80 & 71 & $\mathrm{H}$ & $\mathrm{H}$ \\
\hline & Total Average & 63 & 67 & $\mathrm{M}$ & $\mathrm{H}$ \\
\hline
\end{tabular}

Information : $\mathrm{H} \quad$ : High

$$
\text { M : Medium }
$$

L : Low

The results obtained indicate that the level of perception of respondents in Red Lentera was 63\% categorized as moderate, while the perception of respondents in Badrika Mangrove Tourism Park in mangrove rehabilitation activities was in the high category, namely $67 \%$. The medium category means that people's perceptions / understanding of the mangrove ecosystem already know, but for further public understanding of mangrove ecosystems such as mangrove types and the function and benefits of mangroves, the community does not know yet. For the high category, it means that the community's perception / understanding of the mangrove ecosystem already knows, like they already know the types of mangroves and the functions and benefits of mangroves. Respondents with a low cosmopolitan level are people who do not have broad insight. Cosmopolitan is a person's ability to have broad thinking insights and is supported by the more often the person is looking for information from outside, it will be easy for him to accept something new, especially things that are positive and is renewal, but on the other hand, if someone has a narrow insight, it will certainly be difficult to accept something new [35]. Natural resources cannot be conserved and managed properly without first knowing people's perceptions and attitudes towards the environment [36]. In the another location, research in Tanakeke Island showed that the perceptions and attitudes of the community towards the mangrove ecosystem will influence their support for the success of mangrove conservation efforts. The community's perceptions and attitudes are closely related to the success or failure, or the positive and negative behavior of the community in supporting efforts to conserve the mangrove ecosystem on Tanakeke Island [37]. The Badrika community has experienced the direct benefits of mangroves as tourism and beach protection from abrasion, therefore the people in Badrika Mangrove Tourism Park have started to support the rehabilitation of mangrove ecosystems.

The Lentera Merah community, most of whom are fishermen, have not directly benefited from the 
mangroves, seen from the respondents who were met. If the community's perception is negative or not supportive of the planned mangrove vegetation planting activity, the first thing that must be carried out is to build community awareness of the importance of the mangrove ecosystem and the importance of planting benefits for them through education and counseling. mangroves. Knowledge is a variety of symptoms that humans encounter and acquire through observation of one's mind and knowledge that can affect a person's mindset or level of awareness, attitude or behavior towards the activities he does [38].

\subsubsection{Respondents' Aspirations and Actions in Mangrove Ecosystem Rehabilitation Activities}

The results regarding respondents' aspirations and actions regarding mangrove rehabilitation in the research location are presented in Table 6.

Table 6. Recapitulation of Percentage of Calculation Results regarding Community Aspirations and Actions on Mangrove Rehabilitation Activities (a) Lentera Merah (b) Badrika Mangrove Tourism Park.

\begin{tabular}{|c|c|c|c|c|c|}
\hline \multirow[t]{2}{*}{ No } & \multirow[t]{2}{*}{ Questions } & \multicolumn{2}{|c|}{$\begin{array}{l}\text { Aspiration Value } \\
\text { and Action }(\%)\end{array}$} & \multicolumn{2}{|c|}{ Category } \\
\hline & & A & b & $\mathbf{a}$ & $\mathbf{b}$ \\
\hline 1 & $\begin{array}{l}\text { Community aspirations and actions regarding the need to } \\
\text { implement mangrove rehabilitation activities }\end{array}$ & 80 & 100 & $\mathrm{H}$ & $\mathrm{H}$ \\
\hline 2 & $\begin{array}{l}\text { Aspirations and actions of the community regarding } \\
\text { expectations on the condition of mangrove ecosystem } \\
\text { management }\end{array}$ & 81 & 100 & $\mathrm{H}$ & $\mathrm{H}$ \\
\hline 3 & $\begin{array}{l}\text { Community aspirations and actions regarding involvement in } \\
\text { designing mangrove rehabilitation activities carried out }\end{array}$ & 33 & 33 & $\mathrm{~L}$ & $\mathrm{~L}$ \\
\hline 4 & $\begin{array}{l}\text { Community aspirations and actions regarding involvement in } \\
\text { drafting a budget for mangrove rehabilitation activities carried } \\
\text { out }\end{array}$ & 33 & 33 & $\mathrm{~L}$ & $\mathrm{~L}$ \\
\hline 5 & $\begin{array}{l}\text { Community aspirations and actions regarding involvement in } \\
\text { determining the location of mangrove rehabilitation activities }\end{array}$ & 37 & 33 & $\mathrm{M}$ & $\mathrm{L}$ \\
\hline 6 & $\begin{array}{l}\text { Community aspirations and actions regarding outreach and } \\
\text { socialization activities for mangrove ecosystem activities. }\end{array}$ & 41 & 47 & $\mathrm{M}$ & $\mathrm{M}$ \\
\hline 7 & $\begin{array}{l}\text { Community aspirations and actions regarding mangrove } \\
\text { rehabilitation activities in this area }\end{array}$ & 40 & 39 & M & M \\
\hline 8 & $\begin{array}{l}\text { Community aspirations and actions regarding mangrove } \\
\text { planting activities on their own initiative }\end{array}$ & 43 & 58 & M & M \\
\hline 9 & $\begin{array}{l}\text { Community aspirations and actions regarding their willingness } \\
\text { if their land becomes the location for mangrove rehabilitation }\end{array}$ & 54 & 64 & $\mathrm{M}$ & $\mathrm{M}$ \\
\hline 10 & $\begin{array}{l}\text { Supervision of community implementation in mangrove } \\
\text { rehabilitation activities in this area }\end{array}$ & 44 & 40 & $\mathrm{M}$ & $\mathrm{M}$ \\
\hline 11 & $\begin{array}{l}\text { Community aspirations and actions regarding monitoring the } \\
\text { implementation of mangrove ecosystem rehabilitation in this } \\
\text { area are discussed at a meeting of farmer groups and regional } \\
\text { leaders }\end{array}$ & 33 & 33 & $\mathrm{~L}$ & $\mathrm{~L}$ \\
\hline 12 & $\begin{array}{l}\text { Community aspirations and actions regarding the } \\
\text { implementation of management and maintenance activities for } \\
\text { the mangrove ecosystem in this area }\end{array}$ & 85 & 67 & $\mathrm{H}$ & $\mathrm{M}$ \\
\hline & Total Average & 50 & 54 & M & M \\
\hline
\end{tabular}

Community aspirations and actions in rehabilitation activities starting from planning, implementation, and monitoring are also keys to the success of mangrove ecosystem rehabilitation efforts in each region. The level of community aspirations and rehabilitation activities already exist, such as hopes. Meanwhile, community actions regarding mangrove rehabilitation activities have not fully participated in the mangrove rehabilitation activities and their implementation. Mangrove ecosystem actions in planning, budgeting and determining the location for rehabilitation in Lentera Merah was in the moderate category, namely $50 \%$, while in the Badrika Mangrove Tourism Park location, it was $54 \%$ in the moderate category. Medium category means that community aspirations about mangrove

management, especially in mangrove ecosystem rehabilitation activities from the social perspective of coastal communities, has been quite effective so far, but the community is still not involved in planning, implementation and monitoring. 
The implementation of the planning, utilization, monitoring, control, and rehabilitation programs, hopes that the community will be involved in planning mangrove ecosystem rehabilitation activities in the research location. Rehabilitation activities are carried out to restore the damaged mangrove ecosystem, so that the mangrove ecosystem can function properly. Rehabilitation efforts must involve all levels of society associated with mangrove areas. The rehabilitation of mangrove areas is carried out in accordance with the benefits and functions that should be developed, as well as the aspirations of the community [39].

The community also plays an important role when monitoring the mangrove ecosystem rehabilitation activities, and this is very beneficial for the success of mangrove ecosystem rehabilitation. The social structure and forms of utilization as well as the intensity of interaction of coastal areas by the community need to be known in mangrove ecosystem rehabilitation activities so that target community groups involved, both priorities and non-priorities, can be determined [27]. This is evident in the environment by seeing the function of the mangrove ecosystem as a coastal protection from sea water abrasion as well as a habitat for several types of fish, which greatly affects the productivity level of marine biota including crabs and shellfish, which these organisms have very promising economic value for local communities to increase. income. This does not rule out the possibility that the existence of the mangrove ecosystem indirectly provides direct benefits to the community, such as a place to look for crabs and other biota that can be traded but still pay attention to their environmental conditions [11]. The relationship between humans and nature is basically cultural in the sense of human values regarding the scope of needs or social in nature, including special institutional arrangements involving physical environmental influences both large and small and forest sustainability can only be realized [40]. If there is still a harmonious relationship between humans and forests and uphold the cultural values contained therein.

\section{CONCLUSION}

Data on the structure and vegetation of mangroves in Lentera Merah could not be taken because only a few mangroves were living and scattered. Meanwhile, the mangrove ecosystem as a result of rehabilitation at the Badrika Mangrove Tourism Park location was found in only two categories, namely sapling and seedling. There were two government agencies that were involved in the mangrove rehabilitation program in the two research locations, namely the Watershed and Protection Forest Management Centers (BPDASHL) Ketahun. The role of the Government in mangrove rehabilitation in the two research locations in funding was in the form of mangrove seeds, the government's role in counseling and outreach had not been carried out, while the government's role in monitoring and evaluation activities was low, especially in Lentera Merah. Public perception in Lentera Merah was in the medium category, namely $63 \%$ and in the Badrika Mangrove Tourism Park it was in the high category, namely $67 \%$. Meanwhile, the aspirations and actions at Lentera Merah and the Badrika Mangrove Tourism Park were in the medium category with a value of $50 \%$ and $54 \%$.

\section{REFERENCES}

[1] Supriharyono, Konservasi Ekosistem Sumberdaya Hayati dan Wilayah Pesisir dan Laut Tropis, Yogyakarta: Pustaka Pelajar, 2009.

[2] D.C. Donato, J.B. Kauffman, D. Murdiyarso, S. Kurnianto, M. Stidham, and Kanninen, "Mangrove Salah Satu Hutan Terkaya Karbon di Daerah Tropis," Brief CIFOR, vol. 12, pp. 1-12, 2012.

[3] M. H. Ghufran and K. Kordi, Ekosistem Mangrove, Potensi, fungsi, dan Pengelolaan, Jakarta: PT. Rineka Cipta, 2012.

[4] H. Apriyanti, "Pengendalian Degradasi Sumber Daya Alam Pesisir melalui Pemberdayaan Masyarakat Pesisir," Sekolah Pasca Sarjana IPB, Bogor, 2007.

[5] Zamdial, " Analisis Struktur Komunitas Hutan Mangrove di Desa Pasar Sebelah Kecamatan Kota Mukomuko Kabupaten Mukomuko," Jurnal Enggano, vol. 1, no. 2, pp. 29-37, 2016.

[6] R. Djamaluddin, "The dynamics of mangrove forest in relation to die-back and human use in Bunaken National Park, North Sulawesi, Indonesia.," University of Queensland, Brisbane, 2004

[7] Bahagia, "Peran Pemerintah Daerah dan Partisipasi Masyarakat dalam Rehabilitasi Hutan Mangrove Pasca Tsunami di Kecamatan Baitussalam Tahun 2008," Pasca Sarjana Universitas Sumatera Utara, Medan, 2009.

[8] D. Mueller-Dombois and H. Ellenberg , Aims and Methods of Vegetation Ecology, London: John Wiley, 1974.

[9] Singarimbun and S. Effendi, Metode Penelitian Survai, Edisi revisi, Jakarta: PT. Pustaka LP3ES, 1987.

[10] Riduwan, Rumus dan Data dalam Aplikasi Statistika, Bandung: Alfabeta, 2007.

[11] P.P. Renta, "Kajian Rehabilitasi Mangrove di Desa Klidang Lor, Kabupaten Batang dan Desa Mojo, Kabupaten Pemalang Jawa Tengah," Program Pascasarjana Fakultas Perikanan dan Ilmu Kelautan Universitas Diponegoro, Semarang, 2014.

[12] K. A. McGuinness, "Seed Predation in a Tropical Mangrove Forest : a Test of the Dominance Predation Model in Northern Australia," .Journal of Tropical Ecology, vol. 13 , pp. 293382, 1997.

[13] T. J. Smith, "Seed predation in relation to tree dominance and distribution in mangrove forests," Ecology, vol. 68, pp. 266-273, 1987. 
[14] Supriharyono, Konservasi Ekosistem Sumberdaya Hayati di Wilayah Pesisir dan Laut Tropis, Yogyakarta: Pustaka Pelajar, 2000.

[15] Indriyanto, Ekologi hutan, Jakarta: Bumi Aksara, 2006.

[16] Keputusan Menteri Negara Lingkungan Hidup [KepMenLH], Keputusan Lingkungan Hidup Nomor 201 Tahun 2004 Tentang Kreteria Baku dan Pedoman Penentuan Kerusakan Mangrove, Jakarta: Kementerian Lingkungan Hidup, 2004.

[17] E. P. Odum, Dasar-dasar Ekologi. Diterjemahkan oleh T. Samingan., Yogyakarta: Gajah Mada University press, 1993.

[18] Indriyanto, Ekologi hutan, Jakarta: Bumi Aksara, 2006.

[19] C. W. A. Warongan, " Kajian Ekologi Ekosistem Mangrove untuk Rehabilitasi di Desa Tiwoho Kecamatan Wori Kabupaten Minahasa Utara Prov. Sulawesi Utara.," Pasca Sarjana Institut Pertanian Bogor, Bogor, 2009.

[20] Z. D. Irwanto, Prinsip-prinsip Ekologi Ekosistem Lingkungan dan Pelestariannya, Jakarta: Bumi Aksara, 2007.

[21] P. P. Renta and M. Zainuddin, "Evaluation Of Mangrove Rehabilitation: Ecological Aspects, Perception,Participation And Regulations In Determining Sustainable Management Pemalang Central Java," in Proceeding International Seminar and Expo on Sustainable Utilization of Coastal Resources in Tropical, Bengkulu, 2016.

[22] Keputusan Menteri Negara Lingkungan Hidup [KepMenLH], Keputusan Menteri Negara Lingkungan Hidup Nomor 51 Tahun 2004 Tentang Baku Mutu Air Laut, Jakarta: Kementerian Negara Lingkungan Hidup, 2004.

[23] M. J. Kennish, Ecology of Estuaries; Biological aspect. Vol II, New York: CRC Press, Inc, 1990.

[24] Supriharyono, Konservasi Ekosistem Sumber Daya Hayati di Wilayah Pesisir dan Laut Tropis, Yogyakarta: Pustaka Pelajar, 2007.

[25] As-Syakur, Abd. R, and B. D. Wiyanto, " Studi Kondisi Hidrologis Sebagai Lokasi Penempatan Terumbu Buatan di Perairan Tanjung Benoa Bali," Jurnal Kelautan, vol. 9, no. 1, pp. 85-92, 2016.

[26] Darmadi, M. W. Lewaru, and Khan, "Struktur Komunitas Vegetasi Mangrove Berdasarkan Karakteristik Substrat di Muara Harmin, Desa Cangkring, Kecamatan Cantigi, Kabupaten Indramayu," Jurnal Perikanan dan Kelautan, vol. 3, no. 3, pp. 347-358, 2012.

[27] Y. R. Noor, M. Khazali, I. N. N. Suryadiputra, Panduan Pengenalan Mangrove di Indonesia, Bogor: PKA/WI-IP, 1999.

[28] D. G. Bengen, Pedoman Teknis Pengenalan dan Pengelolaan Ekosistem Mangrove, Bogor: Pusat Kajian Pesisir dan Pulau-Pulau Kecil (PKSPL), 2004
[29] Balai Pengelolaan DAS dan Hutan Lindung Ketahun, "Laporan Evaluasi Tanaman Rehabilitasi Kawasan Hutan Mangrove," Direktorat Jenderal Pengendalian Das dan Hutan Lindung, Jakarta, 2018.

[30] S. Aksornkoae, Ecology and Management of Mangrove, Bangkok: IUCN, 1993.

[31] P.P. Renta, M. Zainuddin, " Evaluation Of Mangrove Rehabilitation: Ecological Aspects, Perception, Participation And Regulations In Determining Sustainable Management Pemalang Central Java," in Proceeding. International Seminar and Expo on Sustainable Utilization of Coastal Resources in Tropical, Bengkulu, 2016.

[32] W. Dunn, Pengantar Analisis Kebijakan Publik Edisi Kedua, Yogyakarta: Gadjah Mada University Press, 2000.

[33] Soetomo, Strategi-Strategi Pembangunan Masyrakat, Yogyakarta: Pustaka Pelajar, 2006.

[34] I. T. C. Wibisono, E. B. Priyanto, and I. N. N. Suryadiputra, Panduan Praktis Rehabilitasi Pantai: Sebuah Pengalaman Merehabilitasi Kawasan Pesisir., Bogor: Wetlands International - Indonesia Program, 2006.

[35] E. Ratnawati, "Tingkat Kepedulian Masyarakat Pesisir dalam Melestarikan Fungsi Hutan Mangrove dan Hutan Payau di Desa Sukabaru Kabupaten Ketapang," Fakultas Kehutanan Universitas Tanjungpura, Pontianak, 2014.

[36] H. F. Lee, and D. D. Zhang, " Perceiving the environment from the lay perspective in desertified areas, northern China," Environmental Management, vol. 41, no. 2, pp. 168-182, 2008

[37] H. Setiawan, H, R. Purwanti, and R. Garsetiasih , "Persepsi dan Sikap Masyarakat terhadap Konservasi Ekosistem Mangrove di Pulau Tanakeke Sulawesi Selatan," Jurnal Penelitian Sosial Dan Ekonomi Kehutanan, vol. 14, no. 1, p. 57-70., 2017.

[38] Milunardi, Fahrizal, and Iskandar, "Partisipasi Masyarakat Sekitar Hutan dalam Melestarikan Hutan Adat sebagai Daerah Penyangga Sumber Air di Desa Menyabo Kecamatan Tayan Hulu Kabupaten Sanggau," Jurnal Hutan Lestari, vol. 2, no. 2, pp. 334-340, 2014.

[39] Prasojo, and Anton, "Masih Efektifkah Kelestarian Hutan Dibangun Melalui Gerhan?," www.kabarindonesia.com., 2008.

[40] H. Fauzi, Pembangunan Hutan Berbasis Kehutanan Sosial., Semarang: Karya Putra 2012. 